\title{
DAMPAK PENERAPAN SISTEM TANAM PAKSA BAGI MASYARAKAT
}

\author{
Oleh : Zulkarnain \\ Pendidikan Sejarah FISE UNY
}

\begin{abstract}
Abstrak
Tulisan ini menjelaskan bahwa sistem tanam paksa adalah politik imprialisme terhadap tanah jajahan yang dianggap sebagai politik tidak bermoral, tidak humanis, dan tidak dapat dibenarkan dalam situasi apapun. Agar tidak salah kaprah ada baiknya kita perlu memahami perbedaan antara sistem itu sendiri yang dianggap tidak dapat dibenarkan, dengan dampak penerapan tanam paksa secara konkret bagi masyarakat Indonesia khususnya di pulau Jawa.

Para peneliti sejarah juga berpendapat bahwa tanam paksa adalah sistem yang revolusioner dan merupakan cikal bakal perubahan tradisi di masyarakat Jawa. Sistem ini bermanfaat karena ekonomi uang telah masuk ke desa-desa, yang kemudian menjadi penggerak roda perekonomian, tenaga buruh menjadi murah dan masyarakat pedesaan mengenal sistem permodalan sehingga terjadi perubahan pola transaksi dari pola transaksi tradisional ke arah pengembangan ekonomi moneter. Sementara penelitian tentang sistem ekonomi masa VOC menunjukkan bahwa proses moneterisasi sesungguhnya telah muncul dalam masyarakat Jawa pada masa VOC.
\end{abstract}

Kata kunci : Dampak, Penerapan, Tanam Paksa.

\section{A. Pendahuluan}

Perang kemerdekaan Belgia dan Perang Diponegoro memerlukan biaya cukup besar, dan untuk menutupi anggaran pembiayaan perang tersebut, Belanda terdorong untuk melakukan kembali politik konservatif dalam mengeksploitasi tanah jajahan. Konsekuensi dari sistem konservativisme ini adalah diberlakukannya Sistem Tanam Paksa atau lebih dikenal dengan cultuurstelsel pada tahun 1830. Selain untuk pembiayaan perang, pemberlakuan sistem tanam paksa bertujuan untuk mendapatkan keuntungan sebesar-besarnya dari tanah jajahan dalam jangka waktu yang relatif singkat. Oleh karenanya pemerintah Hindia Belanda mengerahkan tenaga rakyat tanah jajahan dalam proses penanaman tanaman yang berorientasi ekspor dan bernilai ekonomis tinggi. Sikap konservatif ini bertahan dalam kurun waktu yang cukup lama dengan cara melibatkan penguasa tradisional Jawa, sehingga 
penguasa tradisional secara langsung maupun tidak langsung juga ikut menikmati (MT. Kahin dalam Sartono Kartodirdjo, 2002: 126).

Kemudian muncul pertayaan, apakah akan tetap terjadi perbedaan perkembangan ekonomi seandainya sistem Tanam Paksa tidak pernah diterapkan di tanah Jawa ....?. Bagaimanakah jika sebagai pengganti sistem tanam paksa pemerintah kolonial Belanda tetap menerapkan rencana Van den Bosch ini pada tahun 1830 yakni melanjutkan arah yang telah digambarkan oleh Du Bus seperti yang pernah diterapkan pada tahun 1827.....?. Pertanyaan pertayaan ini terasa sulit untuk dijawab karena peristiwa itu belum pernah terjadi dan hanyalah pegandaiaan belaka, tetapi dengan munculnya pertanyaan tersebut paling tidak dapat merenungkan kecenderungan yang akan terjadi dalam jangka panjang, karena pada dasarnya kebijakan tanam paksa yang diterapkan oleh pemerintah kolonial sepenuhnya mengakomodir pola-pola sosial dan ekonomi yang sudah ada dalam masyarakat Jawa (Aman,2003:12).

Menurut peneliti sejarah, sistem tanam paksa adalah sebuah sistem yang revolusioner dan merupakan cikal bakal atas sebuah perubahan tradsi dalam masyarakat Jawa. Ada tiga hal penting yang merupakan dampak dari penerapan tanam paksa yakni, terjadi pembentukan modal, tenaga kerja yang murah, dan tumbuhnya ekonomi pada masyarakat pedesaan. Sebelum hal ini dibahas ada baiknya disajikan pertimbangan-pertimbangan para penulis sejarah dalam memandang sistem tanam paksa, agar para pembaca dapat memperoleh gambaran secara komperhensif .

\section{B. Penulisan Sejarah Sistem Tanam Paksa}

Penulisan sejarah ekonomi Indonesia abad ke-19, pada dasarnya bisa dipisahkan dari sistem tanam paksa yang dilaksanakan oleh penguasa kolonial Belanda sebagai sebuah kebijakan konservatif-kolonialis dalam rangka meningkatkan eksploitasi di tanah koloni Belanda. Berdasarkan hasil penelitian dan kajian literatur yang ada, ditemukan gambaran yang jelas mengenai pelaksanaan tanam paksa di Indonesia, terutama penerapan tanam paksa di Pulau Jawa. Jika mempelajari secara detil dan mendalam mengenai pelaksanaan tanam paksa di Jawa dengan luar Jawa, maka dengan sangat mudah ditemukan perbedaan mendasar terutama yang berhubungan dengan proses pemiskinan masyarakat pribumi (Zulkarnain,2002:19). Dampak penerapan kebijakan sistem tanam paksa di luar Jawa terhadap penduduk tidak terasa berat, karena rata-rata penduduk memiliki lahan pertanian yang cukup luas, dan lahan-lahan produktif milik penduduk tidak dijadikan obyek pelaksanaan tanam paksa. Sementara lahan yang digunakan untuk budidaya tanam, kebanyakan merupakan lahan tidur yang tidak tergarap. Sementara penggunaan lahan dalam sistem tanam paksa di pulau Jawa, budidaya tanaman tidak hanya dilakukan di lahan-lahan tidur, melainkan di lahan-lahan milik 
petani yang sedianya digunakan untuk tanaman produktif seperti tanaman padi, palawija, tebu, dan sejenisnya.

Penelitian-penelitian pada abad ke-19 tentang sejarah sosial ekonomi di Indonesia, menunjukkan bahwa pelaksanaan sistem Tanam Paksa di daerahdaerah memperlihatkan dampak atau akibat yang berbeda-beda. Di Pulau Jawa, pelaksanaan sistem tersebut telah mendorong kembali suatu pertumbuhan ekspor yang signifikan, di mana Jawa terlibat praktis dalam perdagangan internasional. Dengan keterlibatan tersebut, eksistensi Jawa menjadi semakin penting dan perannya mulai diperhitungkan oleh pemerintah kolonial Belanda, berperannya Jawa dalam lintas makro, bukan berarti meningkatkan kesejahteraan signifikan masyarakat petani Jawa. Meskipun lalu lintas uang menyentuh desa-desa di Jawa yang berdampak terhadap perubahan sistem subsistensi menjadi sistem ekonomi baru, namun secara komprehensif masyarakat pertanian Jawa tetap miskin. Sementara itu pelaksanaan sistem Tanam Paksa di luar Jawa, seperti halnya di Sumatera Barat, telah melahirkan stagnasi ekonomi dan politik dalam masyarakat.

Perubahan sosial dan ekonomi pada abad ke-19 di Pulau Jawa, sebagai daerah utama pelaksanaan sistem Tanam Paksa, menurut kajian antropologi yang digarap oleh Clifford Geertz dengan judul Agricultural Involution: The Process of Ecological Change in Indonesia tahun 1963. Geertz menegaskan bahwa eksploitasi kolonial melalui sistem Tanam Paksa di Jawa telah melahirkan apa yang disebut "involusi pertanian", yang pada gilirannya menciptakan kemiskinan petani di tanah Jawa secara signifikan. Sistem budidaya tanaman ekspor pemerintah kolonial menurut Geertz, membawa dampak perubahan sosial dan ekonomi yang sangat mencolok (Geertz, dalam Suyatno Kartodirdjo, 2003: ix).

Menurut Sartono Kartodirdjo dalam kajian mendalam tentang "Pemberontakan Petani Banten 1888", pemberontakan para petani, merupakan salah satu contoh akibat gangguan praktik ekonomi kolonial. Kemudian gerakan-gerakan yang berupa resistensi petani Jawa pada abad ke-19 mau tidak mau, suka tidak suka harus dikembalikan pada praktik kolonial dengan penerapan sistem Tanam Paksa yang menyertainya. Dalam kajian sejarah sosial ekonomi selanjutnya, resistensi petani Jawa sudah merupakan tradisi masyarakat Jawa terhadap diterapkannya politik ekonomi kolonial yang menyengsarakan. Hal tersebut sangat relevan dengan teori yang disampaikan oleh Selo Soemardjan bahwa dalam masyarakat yang tertindas, maka akan menimbulkan gejolak sosial dari masyarakat yang bersangkutan. Apabila teori tersebut dikaji secara historis, maka resistensi dalam masyarakat Indonesia selalu muncul, mengingat tekanan dan penindasan dari penguasa yang terus berlanjut bahkan sampai sampai sekarang. 
Setelah memahami kajian mengenai pelaksanaan sistem Tanam Paksa, maka gambaran yang diperoleh mengenai perekonomian Jawa bahwa sistem ekonomi modern atau sistem ekonomi uang dan komoditas ekspor, telah mengeksploitasi habis-habisan sistem ekonomi subsistensi yang menjadi basis perekonomian kaum petani. Eksploitasi ekonomi modern melalui penerapan Tanam Paksa merupakan eksploitasi yang bersifat brutal dan mengakibatkan para petani Jawa menderita kemiskinan dan kelaparan berkepanjangan. Teori involusi pertanian karya Clifford Geertz yang menjelaskan proses kemiskinan struktural di Jawa disebabkan oleh pertambahan penduduk Jawa, berkurangnya lahan pertanian, dan perluasan perkebunan Eropa menjadi penyebab utama kemiskinan di Jawa (Clifford Geertz,1966: 124).

Bila peneliti sejarah ingin mengkaji proses penerapan tanam paksa secara obyektif, detil dan medalam ada baiknya para peneliti memotret dari tiga sudut pandang/tiga tahapan, yakni: Tahap pertama, mulai sejak tahuntahun 1850-an dan 1860-an/tahap akhir penrapan tanam paksa, dan berlanjut sampai permulaan dimulai 1920-an, tahapan kedua dari penulisan-penulisan mengenai Tanam Paksa terhitung dari tahun 1920-an sampai akhir kekuasaan kolonial Belanda, dan penulisan tahap ketiga dimulai sesudah kemerdekaan Indonesia dan masih berlanjut sampai sekarang.

\section{Cultur Stelsel Kaitannya Dengan Kehidupan Masyarakat}

Hampir semua peneliti mutakhir menyimpulkan bahwa sistem tanam paksa tidak bermoral, tidak humanis, dan sama sekali tidak dapat dibenarkan dalam situasi apapun. Sehubungan dengan permasalahan tersebut perlu dibedakan antara sistem itu sendiri yang dianggap tidak dapat dibenarkan, dengan dampak penerapan tanam paksa secara konkret bagi masyarakat. Para peneliti belum menemukan kata sepakat mengenai kedua variabel tersebut. Pada satu pihak ada yang berpendapat bahwa sistem ini bermanfaat karena ekonomi uang telah masuk ke desa desa, yang kemudian menjadi penggerak roda perekonomian pada masyarakat pedesaan. Sementara penelitian tentang sistem ekonomi masa VOC menunjukkan bahwa proses moneterisasi sesungguhnya telah muncul dalam masyarakat Jawa pada masa VOC bukan pada masa tanam paksa.

Dalam kaitannya dengan masuknya ekonomi uang ke pedesaan, Prof. Van Niel dari Universitas Hawaii mengemukakan penyertaan modal dalam cultuur stelsel pada awalnya bukan berasal dari orang-orang atau lembagalembaga Barat, karena Belanda pada saat itu sedang dalam keadaan bangkrut sehingga memerlukan sistem tersebut untuk mendatangkan uang dengan cepat. Sementara permodalan yang digunakan untuk pabrik-pabrik gula yang dikelola pihak swasta datangnya justru dari berbagai pihak di Jawa sendiri, seperti 
halnya para pensiunan pegawai negeri, perusahaan ekspor-impor, dan sudah barang tentu para saudagar Cina yang telah lebih dulu memiliki modal yang cukup (Vani Niel, 1988). Jika teori tersebut benar, dapat disimpulkan bahwa moneterisasi memang telah berlangsung jauh sebelum cultuur stelsel diterapkan. Ini berarti bahwa terhadap ekonomi uang masyarakat pedesaan, sistem tanam paksa tidak begitu banyak berdampak.

Sementara itu M.R. Fernando dan O'Malley melalui penelitiannya tentang perkebunan kopi di Cirebon menunjukkan adanya segi-segi positif dari penerapan cultuur stelsel bagi masyarakat Jawa. Dengan meramu pendapat sejumlah sarjana yang pernah meneliti masalah cultuur stelsel seperti Van Niel, Lison R.Knaight, dan Fernando, kedua sejarawan tersebut mengungkapkan bahwa: "... bukti sejarah sudah mulai memperlihatkan bahwa pertumbuhan pertanian komersial sesudah tahun 1830, pada masa ini ekonomi pedesaan memiliki efek rangsangan dengan pola komersialisasi yang mengarah pada peningkatan taraf kehidupan bagi mayoritas penduduk pedesaan, paling tidak selama dasawarsa pertengahan abad ke-19” (Booth, 1988: 236).

Fernando juga mengemukakan bahwa dampak cultuur stelsel adalah: "cara hidup keluarga subsistensi secara berangsur-angsur mengalami perubahan ke arah matrialistik yang komersil. Dengan sistem tersebut penduduk pedesaan semakin terbiasa untuk membeli berbagai macam kebutuhan rumah tangga dengan menggunakan uang. Dampak ekonomi dari kebiasaan konsumen dari penduduk pedesaan itu tercermin dari meningkatnya jumlah penduduk yang melakukan kegiatan-kegiatan ekonomi non-agraris (Fernando, 1991: 3). Tesis Fernando tersebut dibenarkan juga oleh Sugiyanto Padmo dari Uuniversitas Gadjah Mada melalui penelitian historisnya. Secara lebih terperinci Fernando juga menjelaskan dalam sebuah tabel yang menunjukkan diversifikasi pekerjaan masyarakat baik agricultuur maupun non-agricultuur.

Tabel 1.

Komposisi Tenaga Kerja Di Jawa Tahun 1880

\begin{tabular}{|l|c|c|c|c|}
\hline Propinsi & Tani & Manufaktur & Pedagang & Jasa \\
\hline Jabar & 720.532 & 27.628 & 107.855 & 22.678 \\
Jateng & 1103.782 & 49.851 & 174.982 & 34.079 \\
Jatim & 741.660 & 45.271 & 72.896 & 26.023 \\
\hline Jumlah & 2565.974 & 122.270 & 355.733 & 82.780 \\
\hline
\end{tabular}

Fernando, 1993.

Di samping apa yang dikemukakan Fernando, R.E. Elson juga secara khusus meneliti masalah-masalah kemiskinan dengan mengajukan pertanyaan bahwa apakah cultuur stelsel menimbulkan kemiskinan atau tidak bagi 
masyarakat. Elson juga mengakui bahwa masalah tersebut sangat sulit untuk ditetapkan karena keterbatasan sumber sejarah, terutama mengenai data statistik yang kadang membingungkan. Namun ia sampai pada tesis bahwa tidak dapat dikatakan apakah cultuur stelsel menimbulkan kemiskinan pada masyarakat Jawa atau justru sebaliknya mendatangkan kemakmuran. Akhirnya Elson hanya dapat mengemukakan bahwa: "sistem itu langsung atau tidak langsung paling tidak dalam jangka pendek, memberi peluang-peluang untuk suatu pengelolaan secara lebih mantap bagi kehidupan ekonomi pangan serta membuka kemungkinan-kemungkinan untuk pertumbuhan masyarakat tani, yang sebelumnya pilihan hidupnya sangat terbatas" (Elson, 1988).

\section{Pembentukan Modal sebagai dampak Sistem Tanam Paksa}

Sebelum Sistem tanam paksa diperkenalkan pada tahun 1830, orangorang Eropa telah melakukan langkah simpatik dengan cara meninggalkan sistem penyerahan hasil bumi dan pengeluaran ongkos secara paksa yang merupakan ciri khas dari operasi VOC. Adapun para produsen potensial dari komuditi-komuditi pertanian yang dapat di ekspor, pada tahun-tahun 1830 adalah sebagai berikut.

1. Para penduduk desa di pulau Jawa yang menguasai tanah-tanah yang dibebani pajak sewa tanah.

2. Para pengusaha perkebunan swasta, terutama orang-orang Eropa yang memakai tanah yang "tak berharga atau berlebih", dengan membayar sewa kepada pemerintah.

3. Para pengusaha perkebunan swasta, terutama orang-orang Eropa yang mengadakan kontrak dengan pangeran-pangeran Jawa untuk pemakaian hak tunjangan mereka di daerah-daerah kesultanan.

4. Para pemilik tanah partikelir, terutama orang-orang Eropa yang memiliki hak-hak tuan tanah atas tanah-tanah mereka berikut rakyat di atas tanah-tanah itu.

Masing-masing produsen seperti tersebut di atas mengalami kesukaran dalam proses penambahan modal guna memperluas dan meningkatkan operasinya. Sementara lembaga permodalan atau para pengusaha dari orang orang Eropa sebagai satu-satunya jenis modal yang tersedia pada saat itu tidak tertarik menanamkan modal di pulau Jawa. Hal ini di karena mereka mempuyai pengalaman buruk dengan perusahaan-perusahaan perkebunan milik kolonial, yakni pernah mengalami resiko kerugiaannya cukup besar.

Dari empat bentuk pengaturan produksi seperti telah dijelaskan di atas, hanya poin kedua yakni, para pengusaha perkebunan swasta yang mengerjakan tanah dan penyewa dari pemerintah dan peraturan-peraturan perburuhan. Aspek ini kelihatannya mempunyai potensi untuk menarik serta mendapatkan 
modal. Desa di Jawa sama sekali di luar jangkauan keterlibatan ekonomi dan tidak menunjukan budi daya untuk ekspor. Dibiarkan untuk berbuat sekehendaknya, desa memusatkan perhatianya pada mata pencahariannya sendiri, menghasilkan beras, kantum, nila, dan produk- produk yang lain untuk kehidupan sehari hari, lagi pula, karena prosedur resmi yang biasa dipakai di Barat mempunyai pengaruh kecil pada masalah pedesaan, maka tidak ada perlindungan bagi para penanam modal, pengalaman antara tahun 1815 dan 1830 telah memperlihatkan, di mana hasil budi daya untuk diekspor --seperti perkebunan kopi diserakkan pada pengawasan desa, penanaman-penanaman itu diabaikan atau dibiarkan saja produk-produk untuk ekspor, seperti yang diperoleh selama masa ini, berasal dari para pengusaha perkebunan swasta yang menyewa tanah dari tanah bengkok, atau dari daerah-daerah di mana pelaksanaan serah paksa tetap berlaku (Van Niel, 1981).

Sistem Tanam Paksa mempunyai tujuan utama untuk merangsang produksi dan ekspor dari komoditi-komoditi pertanian yang dapat dijual di pasaran dunia. Pemerintah menyadari sejak semula bahwa setiap pengolahan yang diperlukan oleh produk-produk ini, mungkin harus dikembangkan dengan pemasukan-pemasukan modal yang diusahakan oleh pemerintah sendiri untuk melengkapinya. Pemerintah meminjamkan uang kepada orang-orang yang mengadakan perjanjian untuk mendirikan pabrik/penggilingan untuk pengolahan produk-produk pertanian yang disediakan oleh para penduduk desa. Peraturan-peraturan kontrak semacam itu dilaksanakan untuk berbagi hasil panen, tetapi hanya di bidang pembuatan gula, peraturan-peraturan itu menjadi faktor yang banyak artinya dalam usaha menghasilkan pertambahan modal.

Para kontraktor pemerintah bukan saja menerima modal yang dibutuhkan untuk membangun fasilitas-fasilitasnya, tetapi juga mendapat bantuan pemerintah untuk memperoleh batang tebu mentah (raw cane) dan tenaga kerja yang diperlukan. Kontraktor berkewajiban menjual gula yang telah diolah itu kepada pemerintah untuk membayar kembali pinjamannya, tetapi kelebihan jumlah gula yang diperlukan untuk pembayaran kembali pinjaman itu tadi, boleh dijual tersendiri oleh kontraktor demi keuntungannya sendiri. Di sini terdapat peluang untuk menghasilkan uang, dalam jangka waktu beberapa tahun, nilai penjualan-kembali kontrak-kontrak gula ini meningkat pesat.

Sistem Tanam Paksa-melalui suntikan modal dari pemerintah dan melalui penanaman produk yang berorientasi ekspor berimplikasi positip yakni mulai munculnya kepercayaan dari para petani bahwa mereka dapat berkembang, bekerja lebih efesien dan memperoleh keuntungan cukup besar seandainya pemerintah tidak ikut dalam sistem tanam paksa. Kepercayaan diri para petani inilah yang mendorong semangat para petani untuk berjuang dalam 
menigkat tarap hidup yang lebih baik sekaligus sebagai awal mula munculnya pengusaha pengusaha lokal di wilayah pedesaan dan mereka sudah mulai memahami paham tentang menejmen permodalan dalam dunia perdagangan serta mulai berani melepaskan diri dari cengkeraman pemerintahan tradisional mulai dari pemimpin desa sampai ke pemimpin diatasnya secara hirarkis.

\section{E. Tenaga Buruh Murah dalam Sistem Tanam Paksa}

Dalam budi daya tanam yang berorientasi ekspor, keberadaan buruh dengan upah murah merupakan kebutuhan utama dalam sistem tanam paksa. Pengawasan terhadap tenaga buruh pada abad ke-19 merupakan suatu hal yang penting ketimbang pengawasan terhadap tanah. Sistem Tanam Paksa mempekerjakan tenaga buruh dengan menerapkan pola tradisional Jawa yang dapat mengkondisikan tetap eksistensinya keberadaan buruh terutama buruh di pulau Jawa. Hal demikian dimaksudkan agar para petani menyerahkan sebagian hasil perkebunannya kepada pejabat yang lebih tinggi di lingkungannya secara hirarkis seperti yang telah ditentukan oleh penguasa Hindia Belanda (Naessen, 1977). Untuk pekerjaan ini para buruh tidak dibayar, karena pekerjaan tersebut dipandang sebagai suatu pola tata hubungan sosial yang hierarkis sekaligus bentuk penghormatan rakyat terhadap penguasa.

Sebelum diterapkan sistem Tanam Paksa pada awal abad ke-19, pajak atas sewa tanah yang dikenal sebagai sewa tanah, telah berlangsung dalam masyarakat sebagai pengganti penyerahan hasil perkebunan. Untuk memungut pajak, maka desa merupakan unit yang ditunjuk untuk mengorganisasikannya, di samping sebagai unit penyedia serta penyalur pelayanan tenaga kerja paksa yang tanpa pembayaran. Perubahan-perubahan demikian ditinjau dari sudut pandang sosial, ekonomi, maupun politis, menimbulkan kesenjangan dan perpecahan dalam masyarakat Jawa karena mereka mengagap ada diskriminasi perlakuaan sehingga muncul keinginan untuk melakukan protes dan perlawanan.

Sebagaimana VOC sebelumnya, pemerintah kolonial di Hindia Belanda menganggap dirinya sebagai pengganti raja-raja Jawa dan menuntut hak istimewa sebagaimana yang diberikan kepada para pejabat bangsa Jawa yang lebih tinggi kedudukannya. Dalam hak-hak ini termasuk hak atas pelayanan para buruh, seperti yang sebelumnya terjadi untuk membangun sarana dan prasarana seperti pembangunan jalan-jalan, benteng, saluran irigasi, dan sarana-sarana umum dimana pemerintah membayarnya dengan upah yang sangat murah. Kerja paksa yang ditujukan untuk para kepala desa dan juga atasan-atasan dari bangsa Jawa juga meningkat drastis, kendatipun pemerintah berwenang mengawasi apakah terjadi penyalahgunaan wewenang di luar yang ditentukan oleh pemerintah. Harus diakui bahwa peran dan keberadaan kepala desa sangat penting dalam rangka menyalurkan tenaga buruh yang tersedia 
untuk memungut pajak, sehingga pemerintah tidak dapat berbuat banyak tanpa mereka.

Dengan demikian pola-pola tradisional harus tetap dipertahankan agar mendapatkan dukungan dari para kepala desa sebagai perpanjangan tangan pemerintah kolonial. Para petani Jawa bekerja di bawah pemerintah kepala desa, dengan menganggap bahwa pekerjaan itu sebagai persembahan tradisionalnya kepada pejabat-pejabat yang lebih tinggi. Bahkan pengusahapengusaha perkebunan swasta yang mendapatkan tenaga buruh yang diberi upah, harus mengembalikan nilai kerja rodi buruh tersebut. Ada pula yang mendapatkan buruh dengan membayar pajak sebuah desa sehingga mendapatkan hak sebagai tuan besar untuk pelayanan buruh.

Setelah tahun 1830 pemerintah sudah mulai mengenalkan sistem kontrak kerja terhadap petani dengan pemberian upah yang tidak begitu tinggi. Walaupun sistem upah sudah mulai diterapkan tapi para petani atau kaum buruh masih terikat dengan hubungan kekerabatan tradisional Jawa yakni masih tetap memenuhi kewajibannya selaku anggota masyarakat pada perintah desa. Hal ini dikarenakan para petani Jawa belum terbiasa dengan sistem upah, sehingga kegiatan kerja yang mendapat imbalan upah tetap tidak membawa perubahan berarti bagi penigkatan tarap hidup ke arah yang lebih baik. Fenomena ini diakibatkan penduduk sudah terbiasa dengan pola hidup subsistensi yang hanya memenuhi kebutuhan hidupnya sendiri. Di luar itu mereka tetap memandang bahwa bekerja tetap terbatas pada pelayanan wajib kepada penguasa, yang lebih tinggi dan harus dipenuhinya.

Dalam perkembangannya, meningkatnya kebutuhan tenaga buruh, juga diiringi dengan meningkatnya praktek-praktek pemaksaan yang dilakukan oleh para pejabat yang terikat pada pelayanan pemerintah. Seiring dengan bertambahnya jumlah penduduk dan juga tekanan atas tanah-tanah di daerah penanaman pemerintah, maka uang ekstra dari upah makin lama makin penting artinya bagi ketahanan hidup para petani yang lebih miskin. Para penulis tahap pertama banyak memanfaatkan kenyataan, bahwa para penguasa perkebunan dan kontraktor sejak dasawarsa tahun 1840-an ke atas mengatakan bahwa buruh upah bekerja lebih baik dan efisien ketimbang buruh-buruh paksa. Hal ini dapat diterima mengingat tanggung jawabnya sebagai buruh harus tetap dijaga agar tetap dipercaya sebagai buruh yang dibayar. Sementara bagi mereka buruh yang tidak dibayar, maka tidak ada ikatan formal, sehingga tidak mengutakan pelayanan kerja yang baik.

Namun demikian, pada tahun 1850-an, usaha-usaha untuk memasukkan buruh tani ke dalam daerah yang biasanya dikerjakan oleh buruh rodi, harus ditinggalkan, karena tidak ada kaum buruh yang bersedia bekerja dengan tingkat upah yang dijanjikan oleh pemerintah. Sebagian besar petani Jawa tidak belajar menghargai pekerjaan sebagai alat untuk mencapai tujuan, melainkan 
tetap memandang pekerjaan mereka sebagai beban yang harus dipikul dan menjadi derita kesehariannya. Penambahan jumlah kerja paksa yang sangat memberatkan di seluruh daerah penduduk yang lebih luas, mungkin membuka mata para petani, mengenai teknik dan cara-cara bekerja di suatu perkebunan.

Pada tahun 1860-an dan 1870-an, para pengusaha perkebunan swasta mulai mengadakan perjanjian perburuhan dan perjanjian tanah dengan perorangan dan desa-desa, sangat nyata bahwa sistem Tanam Paksa tidak berkontribusi banyak untuk mempersiapkan cara bagi pembentukan pasaran buruh yang bebas dan sukarela. Namun sebaliknya, sistem Tanam Paksa telah menyebabkan penilaian yang negatif bagi pekerjaan karena memberikan kompensasi atau ganti rugi serendah mungkin. Dengan meneruskan penggunaan pola-pola kekuasaan tradisional sistem Tanam Paksa juga menciptakan kebutuhan akan penghasilan tambahan di daerah-daerah di mana penanaman ekspor dapat berkembang. Bagi para pengusaha perkebunan swasta, kondisi tersebut dapat menimbulkan keuntungan maupun kerugian. Keuntungan terletak pada kenyataan akan rendahnya tingkat upah yang sedang berlaku, dan dengan demikian mereka dapat terus bersaing di pasaran dunia. Sementara itu kerugiannya, yang sementara itu lebih besar ketimbang keuntungannya, muncul karena adanya masalah-masalah dalam rangka menarik dan menahan tenaga kerja.

Para pencari tenaga kerja diberikan pada otoritas tradisional, yakni para kepala desa dan tokoh-tokoh pesgusaha lainnya, mereka memberi uang muka terlebih dahulu untuk menarik tenaga kerja, namun demikian masalah yang muncul adalah buruh seringkali tidak masuk kerja sebagaimana tercantum dalam kontrak kerja. Dengan demikian, berbagai tekanan terhadap buruh yang dianggap lalai mereka gunakan. Sementara pengadilan resmi berlangsung lambat dan tidak memadai, lebih efektif memanpaatkan orang-orang kuat untuk memaksa para pekerja. Bahkan kadang-kadang para pengusaha perkebunan dapat membujuk para pejabat administrasi untuk membantu dan memaksa.

Menjelang tahun 1880-an, tekanan pertumbuhan penduduk menjadi jelas dengan berkurangnya lahan garapan yang tersedia, dan semakin terbatasnya kemampuan desa untuk menyiapkan kebutuhan pokok mereka, sehingga banyak orang yang harus mencari tambahan penghidupan di luar desa mereka. Pada saat yang sama berjangkitlah hama tebu dan kopi yang mengakibatkan penurunan drastis hasil tanaman ekspor. Padahal penduduk sudah mulai menggantungkan hidupnya di perkebunan-perkebunan tersebut, sehingga dengan berkurangnya produksi kopi dan gula, maka upah yang diterimakan kepada penduduk juga semakin berkurang. Hal itu masih ditambah dengan munculnya gula bit dari Eropa yang berperan dalam menurunkan harga gula di pasaran dunia internasional menurun. Dampaknya para pengusaha perkebunan menurunkan tingkat upah bagi para buruh, dan mengurangi pula 
jumlah uang untuk penyewaan tanah. Faktor-faktor yang kompleks tersebut mengakibatkan penurunan jumlah uang yang tersedia bagi masyarakat Jawa, yang berdampak pada harusnya kesediaan yang lebih besar dari masyarakat, untuk menerima upah buruh dengan harga dan syarat-syarat yang sebelumnya tidak dapat mereka terima (Elson, 1982).

Penelitian-penelitian yang muncul selama ini khususnya tentang kesejahteraan masyarakat pedesaan Jawa cenderung mendukung gagasan bahwa, di Jawa selama penerapan sistem Tanam Paksa berlangsung terdapat lebih banyak kekayaan materi ketimbang dengan tahun-tahun sesudah pembubarannya. Pengerahan tenaga kerja berdasarkan corvee tradisional Jawa pada umumnya didasarkan pada hak-hak kepemilikan tanah. Kerja menurut pengaturan semacam itu, dihitung berdasarkan suatu sistem yang dikenal dengan cacah rumah tangga, kepala rumah tangga yang mempunyai hak-hak atas tanah juga diwajibkan melaksanakan corvee (tidak menjadi masalah, apakah pekerjaan tersebut dikerjakan sendiri atau menyuruh seorang anggota keluarga untuk melaksanakannya).

Sistem cacah masih berlaku pada 1830, dan lambat laun sistem cacah dihapus oleh Van den Bosch karena setelah tahun 1838 tidak ada lagi rujukan dengan sistem tersebut. Alasannya cukup jelas, di mana untuk pengadaan tenaga kerja sebanyak-banyaknya maka perlu diterapkan pelayan kerja berdasarkan perorangan, bukan atas dasar rumah tangga. Dampaknya, banyak orang yang terlibat dalam pelayanan tanamm paksa tidak lagi mempunyai hak atas tanah. Banyak desa merasa perlu melakukan penyesuaian dengan menyerahkan hak penggunaan sebidang tanah kepada beberapa orang sehingga tenaga mereka dapat diikutsertakan dalam pengaturan kerja yang dibutuhkan oleh sistem Tanam Paksa.

\section{F. Perubahan Ekonomi Pedesaan}

Pelaksanaan sistem Tanam Paksa dalam prakteknya mengikuti pola tradisional yang berlaku dalam masyarakat Jawa, sehingga dapat menggerakan para petani di daerah-daerah tertentu agar mau bekerja dalam menghasilkan tanaman untuk ekspor. Harapan pemerintah adalah dengan menggunakan otoritas kepala desa, dapat menggerakan penduduk untuk mau menyerahkan sebagian tanah untuk kepentingan tanam paksa, dan juga mau bekerja untuk tanaman ekspor. Sikap ini juga dimaksudkan untuk mengkondisikan agar masyarakat Jawa tetap statis.

Kenyataannya hal tersebut tidak terjadi karena dampak ekonomi sistem tersebut justru telah menggerakan perubahan-perubahan dan mempercepat kecenderungan-kecenderungan yang sudah ada. Pola-pola tradisional kalangan atas di tingkat desa sudah kocar-kacir pada permulaan abad ke-19 sehingga sistem Tanam Paksa hanya dapat menggunakan pola-pola itu dengan cara-cara 
yang tidak rasional dan alamiah. Tokoh-tokoh penguasa mengalami tekanantekanan yang semakin berat karena tuntutan-tuntutan sistem tersebut terhadap mereka.

Sistem Tanam Paksa dianggap telah mengubah hak-hak pemilikan tanah dari milik perseorangan menjadi milik bersama, yang tentunya telah merusak hak-hak perseorangan atas tanah yang sebelumnya sudah ada. Hakhak pemilikan tanah merupakan kepentingan subjektif bagi kelompokkelompok pengusaha swasta yang hendak mengganti sistem tersebut dengan bentuk eksploitasi mereka sendiri. Sementara Furnival dan Burger merupakan penulis yang fanatik mendukung kecenderungan tersebut, pembentangan paling jernih dari argumen ini dalam bahasa Ingris didapati pada penelitian Clifford Geertz mengenai involusi pertanian (Geertz, 1963). Dengan memintakan perhatian terhadap bukti-bukti dan kesimpulan-kesimpulan yang dikemukakan oleh para peneliti terdahulu, dalam menjelaskan perkembangan-perkembangan semenjak diperkenalkanya sistem Tanam Paksa, mereka mendapati bahwa telah terjadi homogenisasi sosial di desa-desa Jawa yang mengakibatkan "kemiskinan bersama".

Jauh sebelum sistem Tanam Paksa dilaksanakan, kaum tani Jawa telah menyesuaikan diri secara pleksibel pada kebutuhan-kebutuhan setempat, tempat di mana mereka berada. Sifat-sifat seperti bersedia bekerja keras, kemampuan perorangan, dan penyesuaian kepada perubahan, serupa dengan apa yang telah dikemukakan oleh Selo Soemardjan pada tahun-tahun 1960-an (Selo Soemardjan, 1968). Para pengusaha di atas tingkat desa mengetahui semuanya itu, lalu mengolahnya secara terinci dengan para kepala cacah mereka, yang oleh Hoadley, yang meneliti wilayah Cirebon dan Priangan, dipandang sebagai abdi-abdi para penguasa yang lebih tinggi. Penyesuaian demikian memungkinkan para kepala di atas tingkat desa memenuhi kebutuhan pemerintah akan hasil-hasil pertanian dan tenaga buruh, sambil juga memenuhi kebutuhan mereka sendiri yang meningkat akan tenaga buruh, serta akan lahan penanaman yang lebih luas. Di bawah pengarahan mereka, pemakaian lahan yang tersedia dapat diatur dan penyesuaian-penyesuaian dapat diadakan. Hakhak milik atau hak-hak pengawasan atas lahan berada di tangan para kepala cacah dan golongan elite lokal lainnya.

Berdasarkan kenyataan sistem agraris ini, maka sistem Tanam Paksa diperkenalkan pada tahun 1830. Tujuannya adalah untuk mendapatkan komoditi-komoditi yang dapat dijual di pasaran dunia, dan untuk tujuan tersebut sistem Tanam Paksa memakai lahan dan tenaga kerja dari orang-orang desa di Jawa yang dibujuk atau dipaksa oleh para kepala di atas tingkat desa. Hal tersebut harus dilakukan dalam batas-batas sistem Sewa Tanah (Van Niel, 1964). 
Akhir-akhir ini penelitian sejarah mengetengahkan informasi mengenai apa yang terjadi di desa-desa sesudah tahun 1830, ketika pemerintah mulai menyusun pola-pola produksi baru, informasi tersebut memberikan interpretasi yang berbeda atas kejadian-kejadian, berbeda dengan apa yang telah dikemukakan dalam tulisan-tulisan sebelumnya. Bukti-bukti fisik dari Cirebon, Pekalongan, Jepara, dan Pasuruan, semua daerah dimana penanaman untuk pemerintah telah diperkenalkan, dan memperlihatkan bahwa kepemimpinan desa telah berhasil menarik keuntungan dari kebutuhan-kebutuhan pemerintah itu dan memperkuat kekuasannya dan melakukan pendekatan pribadi di lingkungan struktur pedesaannya (Elson, 1979).

Dengan menggunakan hak-hak tanah mereka, baik secara perorangan maupun kolektif resmi, dan terutama dengan menyalahgunakan tenaga kerja paksa yang berada di bawah pengawasan mereka, memungkinkan bagi mereka untuk melakukan penyesuaian-penyesuaian ke dalam. Dengan cara demikian, mereka mendapatkan keuntungan berlipat ganda, yakni memenuhi kebutuhankebutuhan pemerintah di satu pihak, dan menjadikan dirinya makmur dari hasil pembayaran yang masuk ke desa di lain pihak. Kewenangan pendistribusiannya sangat tergantung dari kehendak para pemimpin tradisional.

Dalam prakteknya, tidak semua desa mengadakan reaksi yang sama, tidak semua peraturan penanaman sama, dan tidak semua perubahan itu terjadi pada waktu yang bersamaan (Fernando, 1982). Jika diamati secara mendalam, maka penelitian-penelitian yang baru memberikan penjelasan-penjelasan yang lebih dapat dipahami, ketimbang terhadap pandangan-pandangan lama tentang pengaturan-pengaturan rumah tangga desa di Jawa sekarang. Dengan menggunakan istilah yang lebih sederhana, maka desa-desa di Jawa masa kini menunjukkan perbedaan sosial yang tegas serta riil antara penduduk desa yang kaya dengan penduduk desa yang miskin. Mereka pada umumnya tidak memperlihatkan pemerataan tingkat sosial maupun homogenitas sosial, yang disangka telah disebabkan oleh penerapan sistem Tanam Paksa, berdasarkan tulisan-tulisan sejarah sosial sebelumnya. Di samping itu, desa-desa masa kini juga menunjukkan suatu kohesi yang kuat, sesuatu yang biasanya tidak akan dilukiskan sebagai suatu pengaruh disintegrasi yang terasa kemudian.

Bagi pengamat Barat terutama pada akhir abad ke-19, penguasaan bersama yang semakin meningkat dari pemilikan lahan itu secara sosial merusak ketertiban desa. Kondisi tersebut menimbulkan kesukaran bagi pengaturan kontrak-kontrak perorangan untuk menyewa tanah atau lahan. Sementara pengaturan penguasaan bersama seringkali tidak meliputi hak penuh atas lahan tersebut, hanya terbatas pada penggunaannya dan juga sama atas hasilnya. Para pemimpin desa, yang hampir tidak pernah secara langsung menggarap lahan, dapat mempertahankan pengawasan sepenuhnya atas sebagian besar lahan-lahan pedesaan tersebut. Pengaturan-pengaturan kontrak 
dalam berbagai bentuk yang luas, tersedia bagi mereka dalam mempertahankan apa yang telah mereka miliki, sementara membiarkan orang lain menjalankan pekerjaan di ladang atau di mana saja.

Para petani kecil yang mandiri, yang bukan merupakan bagian dari lingkaran dalam desa itu atau yang telah melawan kemauan para pemimpin desa, barangkali telah mengakibatkan hidup mereka tersiksa. Secara ekonomis, orang-orang demikian telah mengalami kerugian bahkan dapat dilakukan pemaksaan untuk meninggalkan lahan dan desa mereka. Sedangkan rumah tangga-rumah tangga dan tenaga kerja yang tidak pernah memiliki tanah, tidak begitu terpengaruh oleh otoritas kepala desa, karena mereka di mana pun selalu bekerja untuk orang lain. Oleh sebab itu penguasaan-penguasaan bersama tersebut tampak seolah-olah menghilangkan perbedaan-perbedaan sosial di desa, meskipun sebenarnya tidaklah demikian. Begitu juga keadaan tersebut tidak menimbulkan kesulitan yang berarti bagi para pengusaha perkebunan swasta yang ingin menyewa lahan-lahan pedesaan. Dalam hal ini, sekali lagi biasanya kepala desa menguasai keadaan dan sesuatu persetujuan selalu dapat dicapai.

Dalam struktur golongan sosial dan ekonomi desa ini, peralihan tidak secara keseluruhan mengubah ikatan yang menyatukan desa sebagai suatu kesatuan sosial dan sebagai suatu unit yang produktif. Meskipun para penduduk desa memahami perbedaan-perbedaan sosial dan ekonomi, desa juga tetap merupakan pusat sistem penghidupan bagi sebagian besar penduduk. Benar, orang-orang berpindah ke kota dan mendapat pekerjaan bukan jenis pertanian, sedangkan yang lain-lain menggabungkan diri dengan perusahaanperusahaan yang bergerak di bidang ekspor. Tetapi sebagian besar orang Jawa, tinggal di desanya. Bahkan sebagian dari mereka yang tampaknya sama sekali terpisah, memelihara ikatan dengan desanya dalam berbagai cara. Pengaturan yang sedikit banyaknya bersifat ganda ini, ternyata merupakan salah satu batubatu fondasi dari cara pengaturan tenaga buruh murah yang menguntungkan bagi sektor ekspor dari perekonomian.

Perangkat desa mengumpulkan dan mengelola penyediaan tenaga buruh murah ini, harus mempertahankan ikatan-ikatan dan hubungan-hubungan tradisional agar dapat memenuhi fungsi yang tidak dihapuskan ini dengan cara mengubah buruh-paksa menjadi buruh yang diberi upah, sebab tingkat upah yang rendah tergantung pada simbiose yang berkesinambungan antara ekspor swasta dengan ekonomi pedesaan. Dalam konteks inilah para pemimpin desa harus membangun dan memperluas kekuasaan mereka. Kenyataan-kenyataan itu tidak menyebabkan mereka menjadi petani mandiri yang berorientasi pada pasar, walaupun dalam bidang ini mereka memang melakukan fungsi-fungsi sebagai perantara. Mereka tidak dapat mengabaikan hubungan-hubungan sosial desa, karena desalah satu-satunya yang merupakan tumpuan mereka sebagai 
basis kelembagaan yang tunggal untuk memperoleh kekuasaan dan kekayaan yang berkesinambungan.

Dalam kaitan suatu sistem ekonomi padat karya para pemimpin desa berusaha keras dalam mempertahankan ikatan-ikatan tradisional dan kewajiban-kewajiban sosial. Karena dengan dipertahankannya sistem sosial tradisional, maka para pemimpin desa akan mudah memperoleh tenaga kerja baik untuk kepentingannya sendiri, maupun untuk pengabdian atau melayani pemerintah kolonial. Akhirnya yang menjadi objek pemerasan adalah penduduk, yakni disamping harus memenuhi tuntutan pemerintah kolonial, di sisi lain mereka dituntut untuk tunduk pada para kepala desa sebagai pemimpin tradisional mereka. Tidak heran apabila ketika terjadi resistensi yang dilakukan oleh masyarakat yang merasa tertindas, maka yang paling pertama menjadi sasaran adalah para pemimpin tradisional. Fenomena ini dapat difahami mengingat merekalah para pemimpin tradisional yang dirasa secara langsung melakukan politik eksploitasi terhadap rakyat, baik berkenaan dengan masalah tanah, maupun yang berhubungan dengan tenaga kerja.

\section{G. Penutup}

Dalam pembangunan ekonomi dewasa ini, tampaknya perlu menimba pengalaman-pengalaman masa lampau, misalnya, bagaimana sistem ekonomi modern mempunyai dampak baik positif maupun negatif terhadap sistem ekonomi subsistensi. Sumbangan pemikiran sejarah dalam kajian ekonomi Indonesia abad ke-19 dapat memberikan sebagian jawaban untuk kepentingan yang berarti pada masa sekarang. Demikianlah, sejarah akan menemukan kegunaannya melalui tiga dimensi waktu yakni masa lampau, masa sekarang, dan masa yang akan datang. Konsepsi ini sangat relevan dengan terminologi Allan Nevin yang menegaskan bahwa sejarah adalah jembatan penghubung antara masa lampau, masa sekarang, dan sebagai petunjuk arah ke masa depan. Sejarah dalam bentuknya yang seperti apa pun juga, hendaknya janganlah dianggap hanya sebagai kenangan masa lalu yang tiada guna, melainkan menjadikannya suatu peristiwa bermakna bagi kehidupan riil umat manusia.

Tidak salah lagi bahwa sistem Tanam Paksa yang diterapkan di Hindia Belanda telah mendatangkan perubahan sosial masyarakat baik secara makro maupun mikro. Sistem Tanam Paksa merupakan penghisapan dan pemerasan secara brutal yang dikelola oleh orang-orang yang tamak dan haus akan kekuasaan, yang nilai-nilainya dibentuk oleh latar belakang kebudayaan masing-masing. Sistem Tanam Paksa menjalankan suatu tipu muslihat pada lingkungan sosio-ekonomi secara lebih canggih dan rumit. Dalam membahas sistem Tanam paksa, akan lebih komprehensif apabila dikaji tidak secara tradisional, agar berbagai aspek yang menyertai dilaksanakannya sistem dapat teungkap. Karena jika tidak, maka gambaran utuh dari sistem ini tidak akan 
ditemukan. Namun demikian secara riil adalah tidak dapat diabaikan bahwa pelaksanaan sistem Tanam Paksa menyebabkan adanya pembentukan modal, adanya tenaga murah dan terjadinya perubahan ekonomidi tingkat pedesaan.

\section{Daftar Pustaka}

Anne Booth, William J.O'Malley, Anna Weidemann (ed), 1988. Sejarah Ekonomis Indonesia. Jakarta: LP3ES.

Ardiansyah, Syamsul. Cultuur Procenteen.

Hutagalung, B.R., Batig Sloot dari Cultuurstelsel. Monopoli Perdagangan Opium oleh Pemerintah India-Belanda.

Robert Van Niel, 1992. Java Under the Cultivation System: Collected Writings. Leiden: KITLV Press.

R.E. Elson, 1978. The Cultivation System and 'Agricultural Involution'. Melbourne: Monash University.

C. Fasseur, 1975. Kultuurstelsel en Koloniale Baten: De Nederlandse Exploitatie Van Java 1840-1860. Leiden: University Press.

Wikipedia Indonesia, ensiklopedia bebas berbahasa Indonesia.

Biodata Penulis: Zulkarnain. Lahir di Sumbawa Besar, 9 Agustus 1974. Menamatkan Pendidikan S2 Pendidikan Sejarah Univ. Jakarta. Saat ini sebagai tenaga pengajar pada Program Studi Pendidikan Sejarah FISE Universitas Negeri Yogyakarta dan mengampu mata kuliah Sejarah Ketatanegaraan. 